\title{
SCHENGEN ACQUIS AND ITS IMPLEMENTATION IN LATVIA
}

\author{
Artūrs Gaveika \\ Docent, Dr.iur. Rezekne Academy of Technologies, \\ e-mail: argavs@inbox.lv, Rēzekne, Latvia
}

\begin{abstract}
Latvia joined the Schengen area in 2007 and has already passed three Schengen evaluations. The novelty of the article is aimed at analysis of Schengen Acquis implementation in Latvia and offer suggestions on its further implementation development. The aim of the study is to develop and propose suggestions on Schengen Acquis content improvement and its judicial systematisation development. The research tasks are to investigate the current EU and national normative regulations, legal practices, the conclusions of Latvian and foreign law researchers by using analytical, historical and comparative methods. The improvement of the national normative regulation was started long before Latvia's accession to the Schengen area. The further development of the Schengen acquis is important from the point of view of the right to free movement of persons and from the point of view of ensuring public security in the face of today's challenges related to terrorism, international crime, uncontrolled migration and the spread of disease. The main achievement of the research is that the author has defined the main areas of Schengen Acquis development.
\end{abstract}

Keywords: border security, free movement of persons, public safety, Schengen acquis.

\section{Introduction}

The principles of the State Border Guard's activities, powers, rights and responsibilities and other competences are determined by the Border Guard Law which has been in force for more than 20 years. During this period Latvia has joined the European Union and joined the Schengen area. The normative basis of border guards' activities has developed considerably and has also changed dramatically. The topicality of the research arises from the necessity to develop legislation by the State Border Guard, both in national and international aspects meeting the requirements of the Schengen Area.

The research period is mainly related to the period from 2004, when Latvia joined the European Union and undertook the implementation of European Union legislation in Latvia.

The following methods were used during research:

1) The historical method - studying the development of the Schengen regulatory framework in the historical context, within the framework of the evolution of the European Union and the national regulatory framework;

2) Analytical method - analysing the international, European Union, Schengen and national regulatory enactments, legal practices, knowledge of Latvian and foreign law scholars; 
3) Comparative method - comparing different national laws, as well as relevant European Union and international regulatory framework.

The purpose and tasks of the research are to study the Schengen current normative regulation, legal practices, the findings and conclusions of Latvian and foreign law scholars concerning Schengen acquis implementation aspects and based on research results put forward suggestions on Schengen Acquis implementation development.

Hypothesis - The current Border Guard Law and other legislative acts do not not comply with modern requirements and do not contribute to overall efficiency of the State Border Guard activities. There is a need to further develop appropriate legislation meeting the requirements of the Schengen Acquis.

Approximately five million people use the right to move to another EU member state every year, not counting those who work every day in a neighboring country or those who go abroad to study (Manuskripts, 2004). Belgium, Luxembourg, the Netherlands, Germany and France signed the Schengen Agreement on 14 June 1985 in Schengen Castle on the banks of Moselle river, which is one of the most significant achievements of the free movement of persons on the international scene.

Given the geopolitical significance of this agreement and its direct impact on constitutional law and the sovereignty of the Member States, this would fall within the EU's primary legislation, as pointed out by individual experts - the founding treaties, (Treder, 1998, p 132) since it establishes a single space for the free movement of people.

The Schengen Agreement (1984) consists of a preamble and 33 articles, which are merged into two sections. The agreement abolishes systematic border checks at signatories' common borders, providing for "normal visual observation" of road transport, which does not require its stopping, only reducing speed when crossing the border.

The control is optional, and it must be done in specially designed places, without delaying the movement of other transboundary vehicles, which contradicts the separate EC claims that large-scale infrastructures remain at border crossing points at internal borders, which often results in significant speed limits. The EC believes that Member States must eliminate all of these obstacles to ease traffic. From a control and enforcement standpoint, the positive requirement of the Member States was to require drivers who cross the border to comply with border police and customs regulations to attach a green disc of $8 \mathrm{~cm}$ in front of the vehicle's windscreen (Schengen Agreement, 1984, Art 2, 3, 12). Such a requirement is no longer applied in the modern Schengen area, as there is no regular border control at internal borders, and this provision actually lost its 
meaning, although it is still in the text of the agreement. Significant was Article 5 of the treaty, which allowed the use of dual controls on international highways. Two neighbouring countries were able to use either a common border check with the simultaneous participation of competent officials in a single border check or by carrying out an inspection on their territory only by competent officials of each neighbouring country and only to inbound persons and vehicles, thus saving time and resources for border checks. Such joint border inspection posts were also established on the borders of Latvia with Estonia (Par Nolīguma starp Latvijas Republikas valdību un Igaunijas Republikas valdību par valsts robežas šḳērsošanas vietām un Grozījumu Nolīgumā starp Latvijas Republikas valdību un Igaunijas Republikas valdību par valsts robežas šķērsošanas vietām denonsēšanu, 2011, Art 1) and Lithuania (Par Nolīguma starp Latvijas Republikas valdību un Lietuvas Republikas valdību par sadarbību, veicot kontroli valsts robežas apvienotajos kontrolpunktos, un Protokola par grozījumiem un papildinājumiem Latvijas Republikas valdības un Lietuvas Republikas valdības nolīgumā par sadarbību, veicot kontroli valsts robežas apvienotajos kontrolpunktos, denonsēšanu, 2011, Art 1) until December of 2007 when these countries completely abolished border control at internal borders (LR likums, 2011).

Article 6 of the Treaty laid down a facilitated regime for the crossing of persons in relation to the inhabitants of the territories adjacent to the internal borders of the Member States, allowing them to cross the border outside the border inspection posts in virtually any place and time. This norm was further developed in Article 3 of the Schengen Convention for the concept of local border traffic, which can be extended not only to internal, but in some cases even to the external borders, as is also known in Latvia in the functioning of the border crossing points for local traffic on the state border with Belarus (Agreement between the Government of the Republic of Latvia and the Government of the Republic of Belarus, 2010). According to the agreement, from 1 February 2012 (came into force in 2011), border residents may cross the border with a valid travel document and a local border traffic permit, but a visa is not required. This partly disassociates the implementation of the so-called "compensatory mechanism" provided for in the second section of the Treaty, which includes rules, measures and actions at the external borders and between Member States which would help to prevent the negative consequences of the free movement of persons, that is, crime and illegal immigration prevalence (Schengen Agreement, 1985, Art 9, 17 - 20, 24). Such a "compensatory mechanism" can be triggered by strengthening the status of the EU's external borders by developing and unifying the relevant regulatory framework, reinforcing immigration control in the Member States, achieving more effective and more 
professional border control, improving infrastructure and other measures (Concept of Integrated Management of the State Border of the Republic of Latvia, 2012) as detailed in Articles 2, 6, 7, 8, 27 and other articles.

On December 18, 2019, the Comprehensive Latvian State Border Integrated Management Plan for years 2019-2020 was approved. the Integrated Management approach to national borders supports the establishment of a legal and institutional framework for the activities of the authorities involved, develops common risk analysis products and agrees on common control mechanisms, contributes to more efficient resource management and training provision, enables more efficient use of infrastructure and equipment, and developing cooperation with civil society Unlike the treaty, the Schengen Convention is a larger legislative act, consisting of 142 articles, which are included in 8 titles. The first title consists of the so-called norms of law - definitions. One article formulates important concepts that are used in the convention, such as internal and external borders, third country, border control, etc. (Schengen Convention, 1990, Art 1).

One of the key concepts of the Schengen Convention, which is directly related to the concept of the EU's external border, is the concept of "border control", but it is defined in an ambiguous manner, meaning "control at a border that, irrespective of other considerations, justifies intention to cross the border". The phrase "border control" is not precise as it is not clear whether it is intended to be a border control at the state border or it is in the vicinity of the state border, for example in the border area, as permitted by the Schengen Convention for the implementation of customs control measures, the transportation of narcotic substances and weapons, cross-border pursuit of criminals. More specifically, the content of the concept of "border control" is set out in the Schengen Borders Code and includes border checks and border surveillance (2016). However, these definitions are also unclear, since it is not clear to which external or internal borders the terms mentioned refer.

Differences in the number of different concepts, such as "border checks" (Schengen Convention - control of persons), from other checks and its criteria and ambiguity (Schengen Borders Code, 2016, Art 21), uncertainty in the legal status of border areas, diversity of definition of threats ("public order or national security", "threat to international relations" (Schengen Convention, 1990, Art 2, 5, 6), "threat to public health" (Schengen Borders Code, 2016, Art 2), "serious threat to public policy or internal security" (Schengen Borders Code, 2016, Art 23) and other inaccuracies have led to different interpretations of several basic concepts of the Schengen acquis and, therefore, inconsistency in the implementation of the Schengen Convention. 
In the conclusions of case $\mathrm{C} 348 / 09$, concluded that sexual violence against fourteen year old minor, the satisfaction of violent libido and rape do not fall within the concept of serious (primary) national security reasons in cases where these activities do not directly jeopardise the peace and physical security of the population in general or in a large part of it, even despite the fact that the perpetrator has been punished with a long-term prison sentence and has not even recognised his fault, which increases the risk of recurrence, thus the threat to the public (Yves Bot, Oberbürgermeisterin der Stadt Remscheid I Case C-348/09 P. I. Oberverwaltungsgericht für das Land Nordrhein-Westfalen, 2012).

Contrary to the interpretation of Article 96 of the Schengen Convention on public order and public security, which provides that such a threat may arise from an alien who has been convicted of an offense punishable by imprisonment for at least one year or a foreigner who is reasonably supposed to that he has committed serious criminal offenses, Article 28 of Directive 2004/38 already defines public policy and public security concepts. Article 2 of the Directive states that a Member State may not decide on the expulsion of Union citizens or their family members irrespective of their nationality, who have the right to reside on its territory, except for serious public order or public security reasons (Directive2004/38/EC, Art 28). By contrast, paragraph 3 of Directive 2004/38 provides that an expulsion decision cannot be adopted against EU citizens unless the decision is based on serious national security considerations defined by the Member States where the citizens: (a) have resided in the host Member State for the preceding 10 years; (b) are minors, except where expulsion is necessary in the best interest of the child.

Comparison of the above concepts Article 28 (2) and (3) of Directive $2004 / 38$ clearly indicate the distinction between concepts of public policy and public security, of which the second indicates a higher degree than the first in relation to the circumstances under which the extension to the EU citizens protection may not be applied. The application of both concepts in the field of criminal law corresponds to two distinct criminal law situations. Each Member State defines its public policy with its national law, as it defines the type of conduct prohibited by criminal penalties.

In that regard, it is clear that all provisions of criminal law relate to public policy in such a way that they are mandatory by virtue of their nature and cannot be chosen individually by their will. They are designed precisely to expose individual will, the consequences of which are considered harmful to society's values. Failure to comply with these rules results in a disturbance of the public policy of the Member State, which is greater or less depending on the nature of the criminal offense, since the public order disorder is usually reflected in the penalties imposed by the national 
legislature for the purpose of punishing the prohibited conduct. In each particular case, this assessment and, where applicable, the weighing takes the form of a de facto sanction, which, in the light of the circumstances specific to each case, characterizes the degree of actual offense committed (Yves Bot, Oberbürgermeisterin der Stadt Remscheid I Case C-348/09 P. I. Oberverwaltungsgericht für das Land Nordrhein-Westfalen, 2012).

Latvian Police Lawyer Dr. A.Matvejev points out that public order is an order in public places, which manifests itself in the fulfilment of obligations specified by human subjects in the exercise of their subjective rights and legal norms. Less dangerous offenses that impede public order and public security are classified as administrative violations, for which the Latvian Administrative Violations Code provides for administrative liability (Matvejevs, 2009, pp. 122 - 123).

The problem of the interpretation of the basic concepts of the Schengen acquis is also reflected in some EC complaints concerning complaints by individuals crossing the internal borders of the border area in 2010 due to possible regular inspections carried out in certain internal border areas without barriers to traffic flows at the border crossing points at internal borders and to hinder notification of planned reintroduction of border control at internal borders (EC: On the application of Schengen Borders Code, 2009).

However, somewhat later, the European Commission, concerned about the risk of illegal immigration in Africa by the political crisis in Africa, proposed to provide for stricter application of the Schengen rules and a more structured decision-making mechanism for the temporary reintroduction of border control at internal borders if there is a serious threat to public order or internal security (EC: on strengthening the Schengen Area, 2011).

In exceptional circumstances, border control at internal borders (Schengen Borders Code, 2016, Art 15) may be temporarily restored if there is a serious threat to public order or internal security. The possibility of reintroducing border control at internal borders at EU level has been used several dozen times. In 2018, only by November border control has been restored in six Schengen countries (Temporary Reintroduction of Border Control, 2018). In most cases, the reintroduction of border control has taken place in connection with large-scale sporting events, political demonstrations or high-level political meetings (EK. Schengen governance strengthening the area without internal border controls, 2011). The opportunity to reintroduce border control at internal borders in the Schengen area was used at least 122 times in 2019 (Member States' notifications of the temporary reintroduction of border control at internal borders pursuant to Article 25 et seq. of the Schengen Borders Code). In 
most cases, the reintroduction of border control was linked to the threat of terrorism and illegal migration, large-scale sporting events, political manifestations or government level political meetings (EK. Šengenas pārvaldība - zonas bez kontroles pie iekšêjām robežām stiprināšana, 2011).

For example, in order to avoid possible threats to the NATO Parliamentary Assembly's Spring Session in Riga from 2010 From May 28 to June 1, temporary border control at the internal borders was restored and for 397 persons were found breaches related to use of travel documents at internal borders (Regulations by the Cabinet of Ministers on the temporary reintroduction of border control at internal borders, 2010).

Abolishing persons control at the internal borders allows the border crossing not only citizens but also foreigners who can enter and stay in the Schengen territory for up to 3 months if they have a valid travel document and visa (if required) (Schengen Convention, 1990, Art 5). Article 10 of the Schengen Convention defines the need for visas for foreigners - a uniform Schengen visa is introduced throughout the EU common area, which is valid in all Schengen countries when it is issued for entry into one country (Visa regulations by the Cabinet of Ministers, 2010).

But in this respect, it is important in the context of:

1) referring the concept of "first entry" not only to the first entry (Nicolae Bot, Préfetdu Val-de-Marne, C-241/05, 2006) into the Schengen area, but also to the first entry after the end of the six month period counting from the first entry, as well as any other first entry after any new the end of the six month period from the first day of the first entry which, in the meaning and interpretation of this provision, may cause problems for border crossing parties, as no such information is indicated in the visa (Visa regulations, 2011);

2) the refusal of aliens to enter the Schengen territory if they constitute a threat to public order and security, information obtained from the Schengen Information System at all border inspection posts at the external borders in all Schengen area countries. In the Opinion of Advocate General Mengozzi in Case C 84/12, the conditions for entry in Article 21 and Article 32 (1) of the Visa Code, as well as the risk assessment and grounds for refusal, which are likely to lead to incorrect decision making visa issuance procedure (2013). In addition to the Schengen border code and the Visa Code, the threats to the policy, internal security, public health and international relations of the Member State identified in the grounds for refusing entry are set out in the Visa Code in addition to the conditions for issuing a visa, such as the absence of a threat of illegal immigration, the validity of the purpose of entry, the lodging of a visa application authenticity of documents, medical insurance and availability of means of subsistence (Visa Code, 2009, Art 21, 32). 
The third part of the Schengen Convention, Police and Security, provides for law enforcement cooperation, police surveillance and pursuit, including the crossing of internal borders, by continuing to observe individuals or following criminals in hot pursuit (Matvejevs, 2006, pp. 49 60, 149 - 171). Persons crossing internal borders should be perceived as meeting the conditions of entry and have already been inspected at one of the Member States' external borders. However, regardless of the accuracy and integrity of border controls in a Member State, when aliens stay in the territory of the Schengen Convention Member States may change the legal basis for stay (the validity of the travel document or visa expires, the travel document is lost, the legal basis for stay, etc.). In such cases, individuals continue to move freely throughout the Schengen area, creating a significant risk of illegal immigration. The provisions of the Schengen acquis require the Member States to implement systematic "compensatory" measures when removing border control at internal borders (Gaveika, 2009, pp. 127 133).

Until the abolition of border control at the internal borders, border checks were essential for the prevention of delinquency, since all persons were fully registered during the border checks and the law enforcement agencies were able to determine the fact of entry and exit of the persons. When carrying out border checks at all borders, the illegal entry into the country did not create a high risk and it was insignificant (Public reports of the State Border Guard on years 2002 - 2011). Unfortunately, in the case of the restoration of border control Regulations by the (Cabinet of Ministers on the temporary reintroduction of border control at internal borders, 2010) at internal borders, the number of offenses is increasing sharply (in 7 days period in 2007 when systematic border checks were carried out - 184 offenses were detected, and in 2010, during the same period when the border checks were restored - 376 offenses were detected) (Gaveika, 2018), which in general indicates that "compensatory measures" are ineffective, furthermore, given the fact that the public is warned in advance in all Member States about the time and place of the restoration of border checks. It is the task of a Member State of the Schengen Convention to inform the EC six weeks in advance (except in cases of urgency) that it assesses the validity of such measures and informs the public (Schengen Borders Code, 2016, Art 26 - 30) in the future, but the task of informing the public in the Ministry of Internal Affairs in Latvia (Law on the state border of the Republic of Latvia, 2009, Art 28). Consequently, the actual extent of cross-border delinquency at internal borders, when border checks are not carried out, cannot be precisely determined.

The fourth part of the Schengen Convention "Schengen Information System", which provides for a global information system for combating 
delinquency and cooperation between the Member States, is very important in the work of law enforcement authorities. The use of the SIS involves significant changes in the regulation of the immigration process in each of the Schengen Member States (Grenzüberschreitende polizeiliche Zusammenarbeit zwischen den Schengen-Staaten im EU Rahmen, 1999, S 147 ) in order to strengthen public order and security in the territory of the Member States by ensuring the availability of reports to the competent institutions and authorities (Law on operation of the Schengen Information System, 2007, Art 1) of the Member States, although these reports sometimes lack sufficient justification for public order interests to ban entry for specific persons (ECJ case on $31^{\text {st }}$ January 2006 C-503/03 Commission v Spain, 2003).

The SIS is a common database of law enforcement agencies, in which, by 2012 , more than 40 million alerts (up by about $3 \%$ per month) from 28 countries (Šengenas informācijas sistēma, 2014), including Romania and Bulgaria, were entered, although they are still not members of the Schengen area (EU Council Decision of 29 June 2010 on the implementation of the provisions of the Schengen acquis relating to the Schengen Information System in the Republic of Bulgaria and Romania, 2010).

Since 2008 by 2013 the total number of SIS alerts increased from 22.9 to 44 million (Schengen. Your gateway to free movement in Europe, 2013). The capacity of the SIS database was limited due to technical limitations. It was planned that by 2008 December 31 a new system of SIS II with the use of biometrics and the integration of national information systems will come into operation, which ultimately only started in 2013 in May (the Ministry of the Interior of the Republic of Latvia).

Currently, the Schengen Information System is used by law enforcement authorities of 28 European Union and European Economic Area countries (Iceland, Norway, Switzerland, and Liechtenstein) and the total number of alerts in the Schengen Information System exceeds 40 million. At the end of 2017, SIS contained approximately 76.5 million records, it was accessed 5.2 billion times and secured 243,818 hits (when a search leads to an alert and authorities confirm it) (Schengen Information System, 2020).

The sixth part of the Schengen Convention, entitled "Protection of Personal Data", aims to protect the human right to privacy. The SIS operation law in Latvia specifies the authorities responsible for including the reports in the system and the institutions that have access to the reports already included, as well as the priority requirements (Law on operation of the Schengen Information System, 2007, Art 12, 14) of the reports, also introducing new information technology solutions, incl. the use of biometric 
data (Biometric data protection system law 2009, Art 1) and ensuring the protection of personal data - auditing at least once every four years.

With regard to the protection of personal data, the author does not agree with E. Krutova's statement that it is not possible to provide control in the practical work or information indirectly not used outside the purpose of the provision, as the SIS information is nevertheless protected both by the personalization of users and the control of cases and objectives of the system's use. One cannot agree with E..Krutova's opinion that the SIS and the Prüm information system (as regards the use of DNA profiles in the fight against terrorism and cross-border crime) (Krutova, 2011, pp 145 - 149) would be indistinguishable as the DNA is also a biometric data and the creation of separate information systems for individual biometric data or specific issues (crimes types) is destructive.

Chapter 7 of the Convention establishes responsibility for examining asylum applications and seeks to standardize and unify the application of asylum law in the light of the Geneva Convention on Refugee Status and the Dublin Convention, which basically implements the Schengen Convention's asylum provisions, including several directives. Chapter 7 of the Convention establishes responsibility for examining asylum applications and seeks to standardize and unify the application of asylum law in the light of the Geneva Convention on Refugee Status and the Dublin Convention, which basically implements the Schengen Convention's asylum provisions, including several directives.

\section{Conclusions}

1. The Schengen Agreement and the Schengen Convention are one of the most significant achievements for free movement of persons on the international scale. Given the geopolitical importance of these treaties and the most direct impact on constitutional rights and the sovereignty of the Member States, they should be part of the EU's founding treaties, since they create a single space for the free movement of persons.

2. Until the abolition of border control at the internal borders, border checks were essential for the prevention of delinquency, since all persons were fully registered at the borderchecks and the law enforcement agencies were able to determine the fact of entry and exit of persons.

3. An essential achievement of the Schengen agreement is the introduction of a "Compensatory measures" by providing such regulations, measures and actions that would help to prevent the negative consequences of the free movement of persons. In the event of border checks being restored at internal borders, the number of offenses is increasing rapidly. The number of offenses is also increasing every year in the control of 
immigration at internal borders, which in general shows an insufficient effectiveness of the "compensatory measures".

4. One of the main concepts of the Schengen Convention, "border control", is defined uncertainly, meaning "control at a border that, irrespective of other considerations, justifies the intention to cross the border". The phrase "border control" is not specific, since it is not explicitly stated whether it is a border check at the state border, which the Schengen Convention does not define separately, or it is a control near the national border, for example in the border area, as permitted by the Schengen Convention for the control of customs drug trafficking and weapons trafficking, cross-border pursuit of criminals.

5. At the EU level, there are no unified and precise definitions of the threats to national policies, internal security, public health, international relations identified by the Schengen Borders Code as grounds for refusing entry, but the Visa Code further sets out the conditions for issuing a visa, such as the absence of illegal immigration threats, the justification for the purpose of entry, the authenticity of the visa application documents submitted, the medical insurance and the availability of means of subsistence.

\section{References}

1. Agreement between the Government of the Republic of Latvia and the Government of the Republic of Belarus on the Simplification of Intercity Travel between the Republic of Latvia and the Republic of Belarus: 23.08.2010. Rīga: LV, 2011. 9.dec., nr.194.

2. Biometric data protection system law: Law of the Republic of Latvia. LV, May 21, 2009, No 90.

3. Concept of Integrated Management of the State Border of the Republic of Latvia. Rīga: 16.07.2012. Retrieved August 4, 2020, from http://www.mk.gov.lv/lv/mk/tap/?pid=40257019

4. Directive $2004 / 38 / \mathrm{EC}$ on the right of citizens of the Union and their family members to move and reside freely within the territory of the Member States amending Regulation (EEC) No 1612/68 and repealing Directives 64/221/EEC, 68/360/EEC, 72/194/EEC, 73/148/EEC, 75/34/EEC, 75/35/EEC, 90/364/EEC, 90/365/EEC and 93/96/EEC. August 4, 2020, from https://eur-lex.europa.eu/legal-content/EN/TXT/HTML/?uri=CELEX:02004L003 8-20110616\&from=LV

5. EK Preses un Komunikāciju generāldirektorāts. Eiropa kustībā. Brīvība, drošība un taisnīgums visiem. Tieslietas un iekšlietas Eiropas Savienībā. Manuskripts, 2004. $\begin{array}{llll}\text { Retrieved August } & \text { 4, 2020, from }\end{array}$ ec.europa.eu/publications/booklets/move/42/lv.doc

6. EK. Šengenas pārvaldība - zonas bez kontroles pie iekšējām robežām stiprināšana. Brisele: 2011, 16.sep., COM(2011) 561 galīgā redakcija. EK paziņojums. Retrieved August 4, 2020, from http://eur-lex.europa.eu/LexUriServ/LexUriServ.do?uri 
7. EK: Par Šengenas robežu kodeksa piemērošanu (2010). Publicēts: LV, 2010. 15.okt., nr.164.

8. $\quad$ EK: Par Šengenas zonas stiprināšanu (2011). Publicēts: LV, 2011. 28.sep., nr.153.

9. ES Padomes 2010.gada 29.jūnija Lēmums par Šengenas acquis noteikumu īstenošanu saistībā ar Šengenas Informācijas sistēmu Bulgārijas Republikā un Rumānijā. (2010/365/ES). Retrieved August 4, 2020, from http://eur-lex.europa.eu/Notice.do?mode=dbl\&lang=lv\&ihmlang=lv\&lng1=lv,lv\&ln g2=bg,cs,da,de,el,en,es,et,fi,fr,hu,it,lt,lv,mt,nl,pl,pt,ro,sk,sl,sv,\&val=518813:cs

10. EST 2006.g. 3.okt. spriedums Lietā C-241/05 parlūgumusniegtprejudiciālunolēmumuatbilstoši EKL 68. un 234. pantam, ko Conseild'État (Francija) iesniedza ar lēmumu, kas pieņemts 2005. gada 9. Maijā un kas Tiesā reǵistrēts 2005. gada 2. jūnijā, tiesvedībā Nicolae Bo tpret Préfetdu Val-de-Marne. Retrieved August 4, 2020, from http://eur-lex.europa.eu/LexUriServ/LexUriServ.do?uri=CELEX:62005CJ0241:LV: HTML

11. EST 2006.g. 31.jan. spriedums Lietā C-503/03 Eiropas Kopienu Komisija pret Spānijas Karalisti. Retrieved August 4, 2020, from http://eur-lex.europa.eu/Notice.do?mode=dbl\&lang=en\&lng1=en,lv\&lng2=cs,da,d e,el,en,es,et,fi,fr,hu,it,lt,lv,mt,nl,pl,pt,sk,sl,sv,\&val=421201:cs

12. GAVEIKA, A. (2009). Šengenas Konvencija, mūsdienu izaicinājumi. No: DU starpt. zin. konf. rakstu krājuma. Daugavpils: Saule, pp 127.-133.

13. G̣enerāladvokāta Īva Bota [YVES BOT] 2012.g. 6.marta Secinājumi Lietā C-348/09 P. I. pret Oberbürgermeisterin der Stadt Remscheid (Oberverwaltungsgericht für das Land Nordrhein-Westfalen (Vācija). Retrieved August 4, 2020, from http://eur-lex.europa.eu/LexUriServ/LexUriServ.do?uri=CELEX:62009CC0348:LV: HTML

14. Ģenerāladvokāta P.Mengoci (Paolo Mengozzi) 2013.g. 11.apr. secinājumi Lietā C-84/12 Rahmanian Koushkaki pret Bundesrepublik Deutschland. Retrieved August 4, 2020, from http://eur-lex.europa.eu/LexUriServ/LexUriServ.do?uri=CELEX:62012CC0084:LV: HTML

15. Grenzüberschreitende polizeiliche Zusammenarbeit zwischen den Schengen-Staaten im EU Rahmen. Heranführung der Staaten Mittel-und Osteuropas (1999). Seminar. Weimar: Thüringerr Polizeiverwaltungsamt, s.147.

16. KRUTOVA, Ē. (2011). Starpvalstu sadarbība transnacionālo organizēto noziegumu izmeklēšanā. Rīga: 145.-149.lpp.

17. Law on operation of the Schengen Information System (2007). Law of the Republic of Latvia, adopted on June 14, 2007, No 102.

18. LR IeM. Prezidentūra. (2015). Retrieved August 4, 2020, from http://www.iem.gov.lv/lat/eiropas_savieniba/prezidentura/?ins_print=1

19. LR MK. Stājas spēkā Latvijas - Baltkrievijas vienošanās par pierobežas teritoriju iedzīvotāju savstarpējo braucienu vienkāršošanu. 29.11.2011. Retrieved August 4, 2020, from http://www.mk.gov.lv/aktuali/zinas/2011gads/11/291111-am-18/?print

20. MATVEJEVS, A. (2006). Šengena. Informatīvie materiāli. Rīga: LPA, pp.149.-171; 49.-60.

21. MATVEJEVS, A. (2009). Policijas darbības teorijas attīstības tendences. Rīga: Petrovskis un Ko, pp.122.-123. 
22. Par Nolīguma starp Latvijas Republikas valdību un Igaunijas Republikas valdību par valsts robežas škērsošanas vietām un Grozījumu Nolīgumā starp Latvijas Republikas valdību un Igaunijas Public reports of the State Border Guard on years 2002- 2011. Retrieved August 4, 2020, http://www.rs.gov.lv/index.php?id=904\&top=904 .

23. Par Nolīguma starp Latvijas Republikas valdību un Lietuvas Republikas valdību par sadarbību, veicot kontroli valsts robežas apvienotajos kontrolpunktos, un Protokola par grozījumiem un papildinājumiem Latvijas Republikas valdības un Lietuvas Republikas valdības nolīgumā par sadarbību, veicot kontroli valsts robežas apvienotajos kontrolpunktos, denonsēšanu: LR likums. LV, 2011. 19.maijs, nr. 88.

24. Regulations by the Cabinet of Ministers on the temporary reintroduction of border control at internal borders on May 12, 2010 No 254. (prot. No.22 24.§) LV, May 14, 2010, No 76.

25. Republikas valdību par valsts robežas šksērsošanas vietām denonsēšanu: LR likums. LV, 2011. 19.maijs, nr.88.

26. Research project, 2017.The EU's external border security, Latvian internal security. Nr.1.1.1.2./VIAA/1/16/127. Retrieved August 4, 2020, from http://www.rta.lv/pecdoktoranturas_petniecibas_atbalsts

27. Schengen Agreement (1984). Retrieved August 4, 2020, from https://eurlex.europa.eu/legalcontent/LV/TXT/HTML/?uri=CELEX:42000A0922(01)\&from=EN

28. Schengen Borders Code (2016). Retrieved August 4, 2020, from https://eurlex.europa.eu/legal-content/LV/TXT/?uri=CELEX:32016R0399.

29. Schengen Convention (1990). Retrieved August 4, 2020, from http://www.refworld.org/docid/3ae6b38a20.html

30. Šengena. Tavi vārti uz brīvu pārvietošanos Eiropā. ES: 2013. Retrieved August 4, 2020, from http://www.consilium.europa.eu/uedocs/cms_data/librairie/PDF/QC3012122LV C.pdf.

31. Šengenas informācijas sistēma (2014). Retrieved August 4, 2020, from http://www.vp.gov.lv/?id=620

32. Šengenas informācijas sistēmas darbības likums, LR likums. LV, 2007, 14.jūnijs, nr.102, 12. un 14. pants.

33. Temporary Reintroduction of Border Control (2018). Retrieved August 4, 2020, from https://ec.europa.eu/home-affairs/what-we-do/policies/borders-andvisas/schengen/reintroduction-border-control_en

34. TREDER, L (1998). Methoden und Technik der Rechtsanwendung: eine systematische Einführung mit Beispielen. Heidelberg Müller, S.132.

35. Visa Code (2009). Retrieved August 4, 2020, from https://eur-lex.europa.eu/legalcontent/EN/ALL/?uri=CELEX:32009R0810 21

36. Visa regulations by the Cabinet of Ministers; August 30, 2011 No 676, No 144, 2011, No144. 